\title{
Natural Enrichment of Trace Elements in Surface Horizons of Calcareous Soils (La Mancha, Spain)
}

\author{
Sandra Bravo Martín-Consuegra, ${ }^{1,2}$ Jose A. Amorós Ortíz-Villajos, ${ }^{1,2}$ \\ Caridad Pérez-de-los-Reyes, ${ }^{1,2}$ Francisco J. García Navarro, ${ }^{1,2}$ \\ Rolando Ruedas Luna, ${ }^{3}$ and Raimundo Jiménez Ballesta ${ }^{2,4}$ \\ ${ }^{1}$ Escuela de Ingenieros Agrónomos, UCLM, Ronda de Calatrava 7, 13071 Ciudad Real, Spain \\ ${ }^{2}$ Instituto de Geología Aplicada, Escuela de Ingenieros Agrónomos de Ciudad Real, Universidad de Castilla-La Mancha, \\ Ronda de Calatrava 7, 13071 Ciudad Real, Spain \\ ${ }^{3}$ Departamento de Investigación en Ciencias Agrarias, Benemérita Universidad Autónoma de Puebla, 72570 Puebla, PUE, Mexico \\ ${ }^{4}$ Departamento de Geología y Geoquímica, Facultad de Ciencias, Universidad Autónoma de Madrid, Campus Cantoblanco, \\ 28049 Madrid, Spain
}

Correspondence should be addressed to Jose A. Amorós Ortíz-Villajos; joseangel.amoros@uclm.es

Received 25 November 2014; Accepted 13 March 2015

Academic Editor: Clara Cilindre

Copyright (c) 2015 Sandra Bravo Martín-Consuegra et al. This is an open access article distributed under the Creative Commons Attribution License, which permits unrestricted use, distribution, and reproduction in any medium, provided the original work is properly cited.

\begin{abstract}
The study of five soil profiles developed on carbonatic sediments of Tertiary Miocene origin has been carried out. The topography of the area was basically flat and the traditional uses of the soils are the cultivation of dry cereals and grapevine. The geochemical characterization of the aforementioned profiles involves a study of the contents of major and trace elements among other pedologic aspects (texture, $\mathrm{pH}$, organic matter, etc.). The results of this study also indicate a superficial enrichment of trace elements due to the leaching of $\mathrm{Ca}$ and moderate biological and anthropic activity. We can consider strontium, Sr, as the trace element that characterizes these limy soils $(435 \mathrm{mg} / \mathrm{kg}$ average content in total soil and $708 \mathrm{mg} / \mathrm{kg}$ in the original rock). These contents are similar to the average value in Castilla-La Mancha of $380 \mathrm{mg} / \mathrm{kg}$ and are higher than the average in world soils of about $200 \mathrm{mg} / \mathrm{kg}$. High levels of dangerous or pollutant elements $(\mathrm{Cd}, \mathrm{Hg}, \mathrm{Pb}, \mathrm{Cu}, \mathrm{Zn}$, or $\mathrm{Ni}$ ) were not detected. The majority of trace element anomalies are related to calcareous material and the leaching of calcium carbonate $(\mathrm{Ca})$, while the influence of the anthropogenic factor is secondary. Soil quality does not indicate toxicity although surficial enrichment suggests a weak threat from consuming crops.
\end{abstract}

\section{Introduction}

Of the 800 million ha of calcareous soils that exist worldwide [1], only 56 million are located in Europe (far less than the number in Asia with more than 300 million and Africa with 200 million, and even behind North America and Australia with 120 million each). Nevertheless, limy European soils (and some Australian and North American soils) have been used for agriculture to cultivate dry cereals and grapevine for the production of quality wines, as is the case of "La Mancha." The term La Mancha denotes the natural region that spreads over provinces of Ciudad Real, Cuenca, Albacete, and Toledo, which lie on south subplateau of the Iberian Peninsula [2].
The study of soils developed over tertiary carbonated materials is relatively common throughout the world [3-5] and particularly in Mediterranean zones [6,7]. The study described here is focused on soils developed on calcareous sediments of Tertiary Miocene origin [8]. These soils, which were formerly called brown calcareous lands "braunerde" [9], constitute $38.5 \%$ of Castilla-La Mancha.

The hydrography of the zone includes the valley of the Guadiana river with its tributaries and part of the Algodor basin that ends in the Tagus river. The high permeability of the materials [10] allows the formation of an extensive hydrogeologic unit (04.04) known as Aquiferous 23, whose natural overflow is the "Tablas de Daimiel" National Park. 
In spite of the fact that different studies have been carried out in surrounding zones $[11,12]$ with similar characteristics and information [8], it can be useful to perform a pedological and geochemical characterization. For this reason, in this work an analysis was carried out on soils developed on calcareous materials, with a topography that is basically flat and traditionally dedicated to the cultivation of Mediterranean crops (cereals, grapevine, and olive tree).

The geochemical characterization mainly concerns knowledge of the contents of major and trace elements. Trace elements are those present in rock or soil at low concentrations (less than $1000 \mathrm{mg} / \mathrm{kg}$ ). The variations observed in the concentrations of elements with depth can be related to mineralogical changes $[13,14]$ or different $\mathrm{pH}$ and Eh values [15]. These elements are always present in the soil and it is possible that anthropic contributions (waste dump, plough, agricultural use, etc.) can increase the initial contents, thus modifying the original balance [16]. In the superficial horizons (topsoils, TS), the high concentration of some elements can disturb certain processes related to the quality of plants life.

The aforementioned trace elements can be uptaken by plants in different proportions and they can be accumulated in different organs and go on to food products obtained from these plants [17]. Recently, the use of trace elements has been proposed to identify the origin of wines from certain zones [18], despite the influence that phytosanitary treatments [19] and the system of winemaking $[20,21]$ can have on the levels of these elements.

There have been guidelines and many papers on content and baseline concentrations in Spanish soils. Some authors [22] and [23] reported the trace element content of soils in the Castilla-La Mancha region. These authors described the effect of pedogenic processes on trace element distribution. They showed that trace element nutrients $(\mathrm{Cu}, \mathrm{Zn})$ are greater in the topsoils than subsoils. Once stated regional baseline concentration levels of trace elements, it is interesting to study soil units for specific and important agricultural use in this region. Castilla-La Mancha has more than 1,500,000 ha for dry cereals and more than 500,000 ha dedicated to vineyard culture [24]. Moreover, the vineyard culture over calcareous soils is widely spread all over the world [25].

The aim of the present work was to ascertain, from the geochemical point of view, the composition of calcareous soils in La Mancha. Secondary, we will compare with regional and world reference baseline concentrations. Finally, we will state if there are accumulation or depletion of the studied chemical elements.

\section{Material and Methods}

2.1. Location and Climate. The large extension of the physiographic area in question (La Mancha plain) explains why, in spite of the distance between profiles (Figure 1), the study of the different soils was carried out together. It can be stated that the 5 soils have a similar evolution, although some variations can be expected: P1 in the slope of a calcareous inselberg, P2 near a quarzitic inselberg with some quarzitic pebbles on

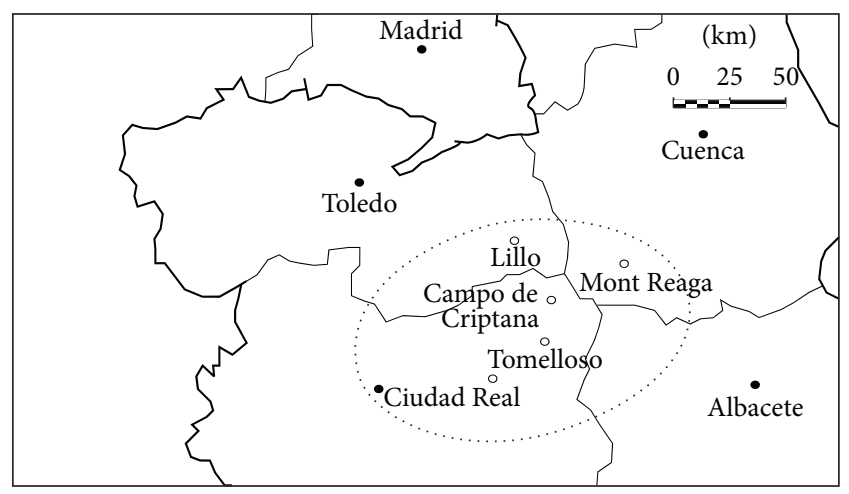

Sampling area

FIGURE 1: Location map of the studied area and sampling soil profile distribution.

the surface horizon, P3 on marls in an extended plain, P4 on reddish marls, and P5 on calcaric fluvial sediments (Table 1).

Among all types of soils dedicated to vineyard and dry cereals culture all over Castilla-La Mancha, the most characteristic class are Petric Calcisols [26] or Petrocalcic Calcixerept [27].

The area under investigation has low rainfall during the year, particularly in summer when there is a xeric period from mid-June to the end of September. The mean temperature is $14.4^{\circ} \mathrm{C}$ and there is a wide temperature range between winter and summer [12].

2.2. Sampling. The samples were taken on profiles opened with a caterpillar machine (approximately $1 \times 1.5$ meters in area and 2 meters in depth, Figure 2). In all cases the soil profile was conditioned using manual tools. The profiles were described according to FAO guidelines [1] and samples were subsequently collected from each horizon for all the profiles and were air dried and sieved $(<2 \mathrm{~mm})$ prior to analysis.

2.3. Analytical Methods. All analytical determinations were carried out according to SCS-USDA guidelines [28]. All quantitative analytical data were obtained in triplicate but only mean value is given.

The soil texture was determined using the hydrometer method [29]. Soil pH was measured in $\mathrm{H}_{2} \mathrm{O}$ and in $0.1 \mathrm{M}$ $\mathrm{KCl}$ using a $1: 2.5 \mathrm{soil} /$ solution ratio. Electrical conductivity was measured in a 1:5 soil/water extract. The method of Olsen [30] was used to estimate available P. The soil organic matter was quantified by the Walkley and Black wet oxidation method [31]. C.E.C. (cation exchange capacity) was determined by acetate ammonic method [32]. Exchangeable $\mathrm{Na}, \mathrm{K}, \mathrm{Ca}$, and $\mathrm{Mg}$ were determined by atomic absorption spectrometry. Total nitrogen content was determined by the Kjeldahl method [33]. The trace element contents samples were determined using an X-ray fluorescence spectrometer (PHILIPS PW 2404) in solid mode with a maximum power of $4 \mathrm{~kW}$ (set of crystal analysers for LiF220, LiF200, Ge, PET and PX1, flow detector, and twinkle detector). Analysis of the 


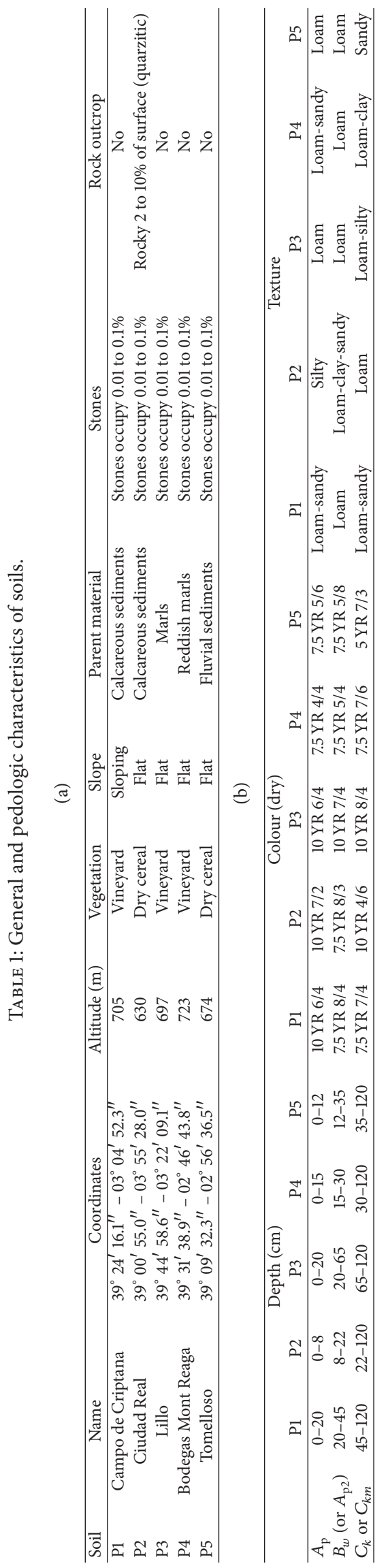



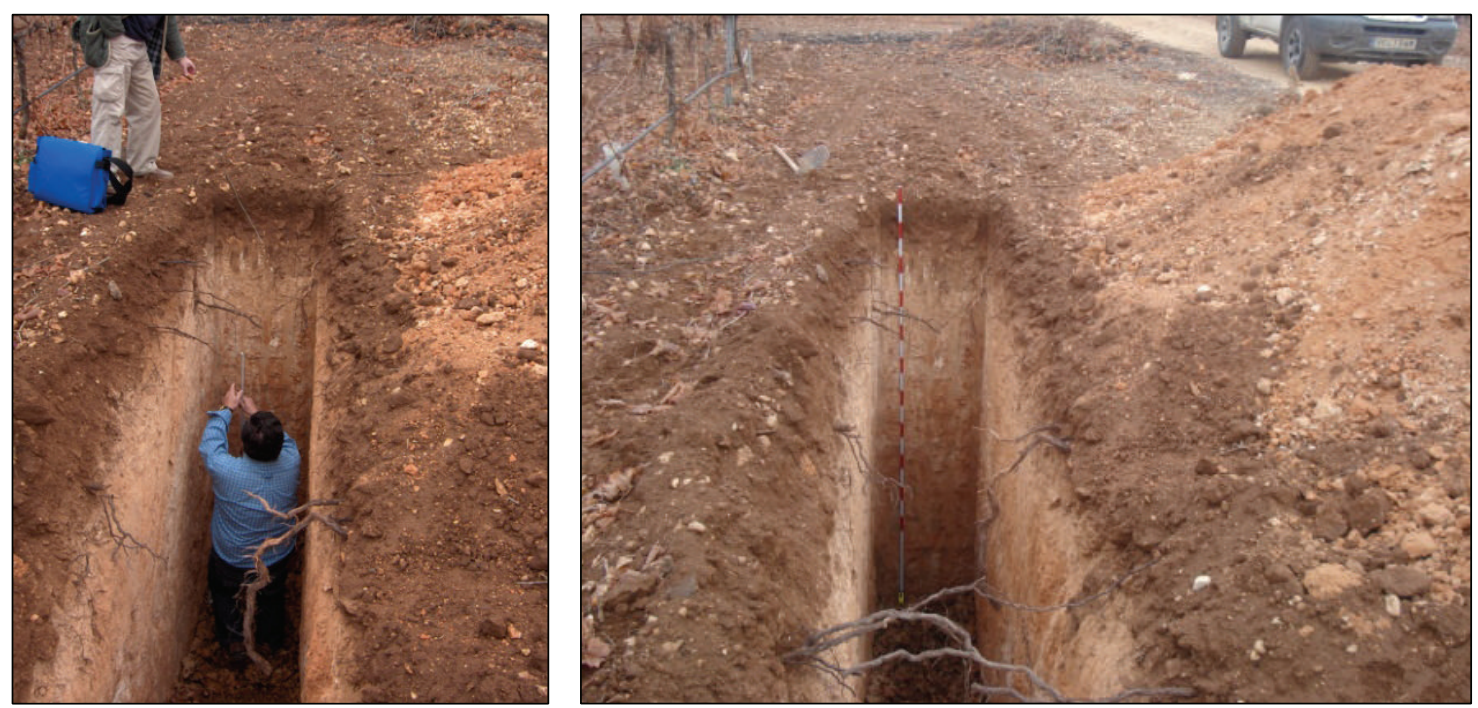

FIGURE 2: Sampling process in P4.

samples was carried out with pearls of lithium borate. Quality control was evaluated by duplicate analysis of certified reference samples (BCR 62, SMR 1573, and SMR 1515).

\section{Results and Discussion}

3.1. Pedologic Characteristics. Table 1 shows the main macromorphological characteristics of soils. The results obtained for the soils under investigation can be described in terms of 3 horizons: An $A_{\mathrm{p}}$ anthropic horizon, a $B_{w}$ cambic horizon with an increase in clay, and a $C$ horizon that consists of the original rock that is weathered to some extent. In this representation the $A_{\mathrm{p} 2}$ horizons of profiles 1 and 4 are assimilated to the $B_{w}$ horizon. In cases where several $C$ horizons appear, the information for the most superficial one will be taken. On the other hand, the depth of the petrocalcic $C_{k}$ horizon is only given up to $120 \mathrm{~cm}$, although in almost all cases it is deeper.

The accumulation of secondary calcium carbonate in deep layers occurs habitually in arid and semiarid conditions [34]. This accumulation leads to the formation of a petrocalcic horizon (called crust or "Caliche") [1].

As it can be seen from the data in Table 1, these soils are not particularly deep, with a maximum depth of $65 \mathrm{~cm}$ and minimum depth of $22 \mathrm{~cm}$ until horizon $C$ appears. The textures of the surface horizons are predominantly loamsandy to loam, with the clay increasing slightly in depth up to a maximum of $18 \%$ in the $B_{w}$ horizon of P1 and P3. In studies carried out on similar soils in the same zone, clay contents have been described that barely reach 20\% [11] and this is consistent with loam-sandy to loam textures. The weak development of the $B_{w}$ horizons (sometimes called $A_{\mathrm{p} 2}$ ) leads us to assimilate the top layers as superficial soils (TS topsoils) in contrast with the limy crust $C_{k}$ or $C_{k m}$. This situation does not occur in other nearby soils, which have developed powerful $B_{t}$ horizons $[12,34]$.
The $\mathrm{pH}$ values measured in water are presented in Table 2 and these are basic in all cases, with values up to 8 (reaching a maximum of 8.5). The values obtained with $\mathrm{KCl}$ are over 7.5 in all cases. The $\mathrm{pH}$ values are similar to those reported for similar soils of the same zone $[8,11]$. These high $\mathrm{pH}$ values contribute to the low mobility of most of the elements, except for Mo and Se [17, 35]. The organic matter content values are as low as one would expect for agricultural soils in a warm and slightly rainy climate.

As it can be seen from the data in Table 2, the C.E.C. of these soils is not high due to the low content in organic matter and clay, particularly if we compare these soils with other surrounding ones $[12,34]$. The exchange complex is in all cases saturated, fundamentally by calcium. The ions $\mathrm{Mg}^{2+}, \mathrm{Na}^{+}$, and $\mathrm{K}^{+}$appear in a lesser extent. Soils with strong "eutric" character [26] are present due to the composition of the original sedimentary rocks and the low rainfall. The fertility of these soils, regarding contents of $\mathrm{P}$ and $\mathrm{K}$ (Table 2), is sufficient for the cultivation of grapevine and dry cereals (traditional utilization, FAO, 2001), although it has often been reported that an abundance of calcium can lead to ferric chlorosis and imbalances in magnesium, potassium, and boron absorption $[15,35]$.

The five profiles studied can be classified as Calcisols [28] or Petrocalcic Calcixerept [27]. The classification is consistent with agroedaphic units described in studies carried out in the same zone $[8,11]$. These are soils that are often weakly developed (Inceptisols) with an intense limestone character due to the original rock and the xeric climate [12].

\subsection{Geochemical Characteristics: Major and Trace Elements.} The major elements provide information about the composition of the soils, their origin, and their relation to the original rock. In our case, horizon $C$ is almost the same as the original rock, albeit slightly weathered and in some cases cemented (petrocalcic). All related data are reported in Table 3. The most important component is $\mathrm{CaO}$, which makes up $80 \%$ of 


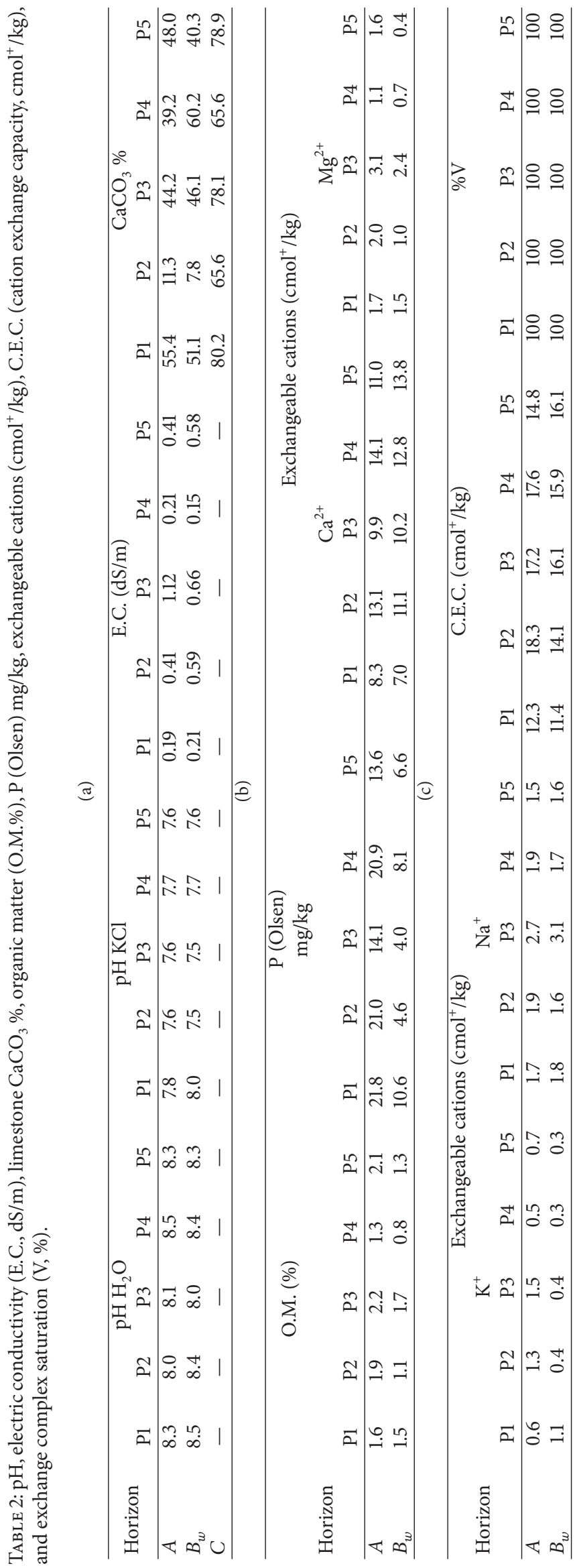


TABle 3: Major elements, from $\mathrm{Na}_{2} \mathrm{O}$ to $\mathrm{N}(\%)$, and trace element contents in each horizon. PPC $=$ losses for calcination. Mean data $(n=3)$.

\begin{tabular}{|c|c|c|c|c|c|c|c|c|c|c|c|c|c|c|c|}
\hline & P1HA & $\mathrm{P} \mathrm{HB}_{w}$ & $\mathrm{P} 1 \mathrm{HC}$ & P2HA & $\mathrm{P}_{2} \mathrm{HB}_{w}$ & $\mathrm{P} 2 \mathrm{HC}$ & P3HA & $\mathrm{P}_{3} \mathrm{HB}_{w}$ & P3HC & P4HA & $\mathrm{P}_{4} \mathrm{HB}_{w}$ & $\mathrm{P} 4 \mathrm{HC}$ & P5HA & $\mathrm{P}_{5} \mathrm{HB}_{w}$ & $\mathrm{P} 5 \mathrm{HC}$ \\
\hline $\mathrm{Na}_{2} \mathrm{O}$ & 0.06 & 0.08 & 0.10 & 0.21 & 0.20 & 0.02 & 0.12 & 0.15 & 0.06 & 0.13 & 0.12 & 0.04 & 0.11 & 0.12 & 0.00 \\
\hline $\mathrm{MgO}$ & 3.34 & 3.58 & 1.23 & 2.01 & 1.81 & 1.13 & 1.12 & 1.08 & 0.43 & 1.40 & 1.40 & 1.40 & 0.98 & 1.02 & 0.30 \\
\hline $\mathrm{Al}_{2} \mathrm{O}_{3}$ & 3.72 & 4.33 & 1.08 & 12.68 & 14.43 & 0.61 & 7.15 & 7.23 & 2.20 & 8.05 & 7.92 & 3.86 & 7.37 & 8.87 & 1.11 \\
\hline $\mathrm{SiO}_{2}$ & 15.27 & 17.92 & 12.97 & 55.53 & 60.46 & 2.62 & 23.39 & 24.37 & 5.43 & 29.47 & 21.12 & 11.72 & 20.76 & 24.18 & 2.70 \\
\hline $\mathrm{P}_{2} \mathrm{O}_{5}$ & 0.17 & 0.19 & 0.03 & 0.39 & 0.27 & 0.03 & 0.16 & 0.11 & 0.03 & 0.16 & 0.12 & 0.07 & 0.17 & 0.17 & 0.04 \\
\hline $\mathrm{SO}_{3}$ & 0.27 & 0.29 & 0.45 & 0.33 & 0.17 & 0.00 & 0.33 & 0.27 & 0.98 & 0.23 & 0.20 & 0.00 & 0.15 & 0.12 & 0.00 \\
\hline $\mathrm{K}_{2} \mathrm{O}$ & 0.74 & 0.94 & 0.35 & 2.87 & 3.08 & 0.07 & 1.33 & 1.22 & 0.22 & 1.34 & 1.25 & 0.40 & 1.21 & 1.37 & 0.13 \\
\hline $\mathrm{CaO}$ & 40.86 & 39.33 & 47.49 & 9.81 & 7.44 & 50.83 & 32.77 & 37.09 & 50.71 & 31.31 & 33.76 & 41.82 & 36.01 & 33.16 & 52.00 \\
\hline $\mathrm{TiO}_{2}$ & 0.18 & 0.22 & 0.07 & 0.73 & 0.84 & 0.04 & 0.35 & 0.35 & 0.11 & 0.42 & 0.47 & 0.23 & 0.37 & 0.47 & 0.07 \\
\hline $\mathrm{MnO}$ & 0.00 & 0.02 & 0.20 & 0.08 & 0.08 & 0.00 & 0.03 & 0.00 & 0.00 & 0.05 & 0.03 & 0.02 & 0.05 & 0.05 & 0.00 \\
\hline $\mathrm{Fe}_{2} \mathrm{O}_{3}$ & 2.19 & 1.32 & 0.10 & 3.93 & 4.13 & 0.24 & 2.09 & 2.15 & 0.64 & 2.30 & 2.42 & 1.16 & 2.34 & 2.70 & 0.38 \\
\hline $\mathrm{N}$ & 0.05 & 0.09 & 0.01 & 0.21 & 0.05 & 0.01 & 0.40 & 0.30 & 0.01 & 0.17 & 0.04 & 0.01 & 0.10 & 0.10 & 0.01 \\
\hline PPC & 31.99 & 31.54 & 35.52 & 11.17 & 6.88 & 44.17 & 31.00 & 25.77 & 39.08 & 25.00 & 30.31 & 39.18 & 30.38 & 27.69 & 43.19 \\
\hline $\mathrm{Sr}$ & 731.4 & 634.4 & 1034.6 & 165.0 & 135.2 & 1499.3 & 297.2 & 315.0 & 240.2 & 277.0 & 165.6 & 400.1 & 144.3 & 126.2 & 367.1 \\
\hline $\mathrm{Ba}$ & 130.5 & 129.0 & 130.6 & 273.1 & 271.6 & 93.9 & 151.3 & 172.0 & 76.4 & 194.1 & 105.7 & 240.0 & 139.5 & 183.6 & 52.0 \\
\hline $\mathrm{Zr}$ & 72.2 & 89.6 & 44.0 & 243.9 & 261.5 & 26.3 & 127.7 & 171.9 & 34.2 & 168.8 & 98.7 & 70.5 & 146.9 & 158.3 & 23.4 \\
\hline $\mathrm{Cr}$ & 15.3 & 17.7 & 13.0 & 62.2 & 67.7 & 20.9 & 21.6 & 23.8 & 12.1 & 29.7 & 22.5 & 16.7 & 28.8 & 36.4 & 11.7 \\
\hline $\mathrm{Ce}$ & 13.4 & 16.1 & 6.1 & 60.0 & 65.3 & 5.0 & 30.0 & 33.6 & 9.2 & 32.4 & 40.8 & 15.7 & 35.7 & 38.8 & 8.5 \\
\hline $\mathrm{Rb}$ & 22.1 & 23.6 & 11.5 & 56.8 & 60.4 & 3.1 & 41.1 & 42.4 & 12.9 & 45.5 & 47.7 & 21.2 & 36.1 & 42.6 & 6.8 \\
\hline $\mathrm{V}$ & 19.0 & 18.7 & 9.3 & 53.4 & 56.0 & 6.4 & 33.1 & 28.1 & 11.2 & 27.7 & 26.6 & 14.8 & 30.9 & 35.6 & 7.2 \\
\hline $\mathrm{Zn}$ & 24.1 & 25.0 & 8.6 & 43.4 & 40.7 & 9.0 & 27.6 & 24.1 & 10.5 & 31.6 & 33.9 & 16.3 & 34.9 & 37.3 & 9.3 \\
\hline $\mathrm{Ni}$ & 10.4 & 9.3 & 5.3 & 27.9 & 28.4 & 9.4 & 12.8 & 12.6 & 6.5 & 13.6 & 12.9 & 12.6 & 13.9 & 15.8 & 4.8 \\
\hline $\mathrm{Pb}$ & 13.5 & 15.3 & 5.8 & 25.8 & 27.7 & 4.7 & 14.2 & 14.1 & 5.6 & 15.1 & 14.9 & 7.0 & 17.0 & 18.7 & 4.2 \\
\hline $\mathrm{Nd}$ & 6.9 & 7.9 & 1.2 & 28.1 & 28.2 & 3.5 & 12.7 & 14.5 & 6.1 & 13.5 & 13.9 & 8.6 & 16.4 & 17.6 & 3.0 \\
\hline $\mathrm{La}$ & 1.9 & 7.4 & 0.0 & 37.1 & 28.1 & 0.0 & 11.3 & 15.0 & 0.0 & 15.2 & 16.3 & 9.4 & 19.2 & 18.5 & 3.4 \\
\hline $\mathrm{Y}$ & 6.7 & 6.9 & 2.9 & 15.4 & 17.4 & 1.2 & 10.4 & 12.3 & 4.5 & 12.5 & 14.7 & 6.4 & 13.7 & 15.8 & 3.0 \\
\hline $\mathrm{Cu}$ & 10.8 & 12.9 & 6.1 & 15.4 & 13.3 & 7.3 & 8.4 & 9.9 & 3.9 & 12.5 & 13.0 & 8.1 & 11.2 & 12.4 & 6.6 \\
\hline As & 10.1 & 9.0 & 12.8 & 9.7 & 11.3 & 9.9 & 12.4 & 15.6 & 13.1 & 14.2 & 16.3 & 10.6 & 14.4 & 13.1 & 3.8 \\
\hline $\mathrm{Nb}$ & 6.6 & 6.8 & 5.2 & 12.3 & 12.8 & 4.9 & 8.5 & 9.0 & 5.5 & 9.5 & 9.7 & 7.0 & 9.0 & 10.1 & 5.1 \\
\hline Co & 5.6 & 5.2 & 3.5 & 9.2 & 9.2 & 6.7 & 6.5 & 6.1 & 6.1 & 6.5 & 7.0 & 4.7 & 6.1 & 6.5 & 5.1 \\
\hline $\mathrm{Ga}$ & 4.1 & 4.2 & 2.3 & 8.0 & 8.3 & 1.7 & 6.4 & 6.4 & 3.2 & 6.4 & 6.5 & 4.1 & 6.6 & 7.8 & 2.2 \\
\hline Th & 2.0 & 2.8 & 0.0 & 9.5 & 9.7 & 0.0 & 6.6 & 7.2 & 2.7 & 7.4 & 7.7 & 3.4 & 6.7 & 8.3 & 2.1 \\
\hline Hf & 2.7 & 3.5 & 2.7 & 7.9 & 7.5 & 1.5 & 2.7 & 5.6 & 0.0 & 4.7 & 5.8 & 3.2 & 3.9 & 3.7 & 2.0 \\
\hline Sc & 1.5 & 1.5 & 0.0 & 9.9 & 9.4 & 0.0 & 5.9 & 4.9 & 0.0 & 4.6 & 3.5 & 0.0 & 3.9 & 6.1 & 0.0 \\
\hline $\mathrm{U}$ & 0.3 & 0.7 & 0.0 & 2.2 & 2.2 & 0.0 & 1.2 & 1.7 & 1.5 & 2.2 & 2.5 & 1.2 & 2.3 & 2.1 & 0.7 \\
\hline W & 0.8 & 0.3 & 0.0 & 1.4 & 2.9 & 0.0 & 2.1 & 0.9 & 0.2 & 1.5 & 1.3 & 1.5 & 0.7 & 0.9 & 0.2 \\
\hline Mo & 1.3 & 0.9 & 1.3 & 0.3 & 0.5 & 1.5 & 0.8 & 1.0 & 1.2 & 1.2 & 1.1 & 1.0 & 0.8 & 1.0 & 0.9 \\
\hline $\mathrm{Ta}$ & 1.0 & 1.2 & 1.7 & 2.4 & 2.0 & 0.0 & 0.8 & 1.4 & 0.0 & 1.8 & 1.5 & 0.0 & 0.9 & 0.0 & 1.2 \\
\hline Cs & 0.0 & 0.0 & 0.0 & 4.2 & 2.6 & 0.0 & 2.7 & 1.9 & 0.0 & 0.0 & 0.9 & 1.1 & 0.5 & 1.5 & 0.0 \\
\hline
\end{tabular}

horizon $C$ (Table 3). The next most important component is $\mathrm{SiO}_{2}$ with an average content in this horizon of $7 \%$, which is very low compared with the majority of sedimentary rocks $[17,36]$.

In the superficial horizons (TS), the original rock of the soil prevails but is attenuated by weathering and by a significant biotic influence. Water surface erosion of the soil (weak slope and xeric climate) had not taken place except in the case of P2, in which the migration of superficial materials had clearly taken place from a nearby hill of quarzitic nature, probably due to ploughing in the same direction of the slope.
We did not eliminate profile P2 in spite of differences with regard to the other four profiles in the surface because it represents a long-standing and common alteration in all of the borders and piedmonts of the quarzitic hills that surround the Mesozoic basin of La Mancha plain [23]. It can be stated that the total contents in calcium carbonate are $55 \%$ average. $\mathrm{SiO}_{2}$ (in proportions near to $30 \%$ ) remains as a residue in the surface due to its greater resistance to weathering. These results are consistent with those reported by other authors $[9,11]$. The content in $\mathrm{Al}_{2} \mathrm{O}_{3}$ also increases up to an average of $8.18 \%$ in superficial horizons. The remaining elements 
reported in Table 4 represent less than 3\% each but they are always present in a greater proportion in top soils than in horizon $C$. It is worth highlighting the increase in $\mathrm{Fe}_{2} \mathrm{O}_{3}$, which is present on average at $2.56 \%$, that is, five times more than in the underlying rock. The lack of iron in the grapevine is a very frequent physiologic accident in La Mancha when the rootstock is not chosen properly $[15,35]$.

All data on trace elements are reported in Table 3. The average total value is less than $1000 \mathrm{mg} / \mathrm{kg}$ (957 mg/kg), of which almost half corresponds to just one element: strontium (Sr).

If one trace element characterizes the limy soils of La Mancha it is probably Sr, with an average content of $435 \mathrm{mg} / \mathrm{kg}$ in the total soil and $708 \mathrm{mg} / \mathrm{kg}$ in the original rock (note that some samples reach $1499 \mathrm{mg} / \mathrm{kg}$ in horizon $\mathrm{C}$ of $\mathrm{P} 2$ ). The $\mathrm{Sr}$ content is consistent with the average value reported for Castilla-La Mancha of $380 \mathrm{mg} / \mathrm{kg}$ [23] and is higher than the value for world soils, which present an average of $200 \mathrm{mg} / \mathrm{kg}$ [17, 36]. In other wine-growing zones such as Oporto, lower levels of Sr were detected $(20 \mathrm{mg} / \mathrm{kg})$ [18]. The geochemical behavior of $\mathrm{Sr}$ is very similar to that of Ca since $\mathrm{Sr}^{2+}$ and $\mathrm{Ca}^{2+}$ ions have similar radium [37]. A low $\mathrm{Ca} / \mathrm{Sr}$ ratio of 8 can lead to toxicity problems with $\mathrm{Sr}$ [17] but this is not the case in the soils described here due to the great abundance of $\mathrm{Ca}$ in all the horizons.

In contrast, two trace elements that are abundant throughout the world are $\mathrm{Ba}(527 \mathrm{mg} / \mathrm{kg})$ and $\mathrm{Zr}(307 \mathrm{mg} / \mathrm{kg})$, very poorly represented in the soils under investigation here (Figure 3). For example, Ba is present at $156 \mathrm{mg} / \mathrm{kg}$ on average $(118 \mathrm{mg} / \mathrm{kg}$ in the original rock) and this value is within the range suggested for sedimentary limy rocks of 50$200 \mathrm{mg} / \mathrm{kg}[17,36]$. The level of $\mathrm{Zr}$ has an average value of $115 \mathrm{mg} / \mathrm{kg}$ (39 mg/kg in the original rock). It is possible to see enrichment in $\mathrm{Zr}$ at the surface as well as $\mathrm{Ti}$ (major element) and Hf due to the fact that these elements (which give tetravalent cations) form compounds that are very resistant to weathering and are linked to the clay fraction of the soil [14]. The Ti/Zr ratio remains constant in the studied profiles (except for a slight discrepancy in P2) and this confirms the common origin and the lithologic continuity [34].

Other elements that are present at low levels (i.e., less than the half the average contents worldwide) $[17,36]$ include $\mathrm{Rb}$ (associated more with granitic rocks) [18], $\mathrm{V}, \mathrm{Zn}$, and $\mathrm{Pb}$ (which accumulate in the clayey fraction of the soils) [34]. Ga and $\mathrm{Sc}$ are very scarce too.

It is interesting to highlight the low content in lanthanides (rare earth elements, REE): Ce (27 mg/kg), La (12 mg/kg), and $\mathrm{Nd}(12 \mathrm{mg} / \mathrm{kg})$. Higher levels have been observed worldwide and in other wine-growing regions such as Oporto [18]: Ce (78 mg/kg), La (40 mg/kg), and $\mathrm{Nd}(35 \mathrm{mg} / \mathrm{kg})$.

The Ni contents are less than $20 \mathrm{mg} / \mathrm{kg}$ in all cases. This level is low in comparison with soils worldwide and with other Mediterranean soils [7], which have higher values related to the presence of serpentine and more acidic $\mathrm{pH}$ values, which in turn improve the mobility of this element [35].

Elements that are required for the diseases treatments of the vineyard, such as $\mathrm{Cu}(10 \mathrm{mg} / \mathrm{kg})$ and $\mathrm{Zn}(25 \mathrm{mg} / \mathrm{kg})$, are
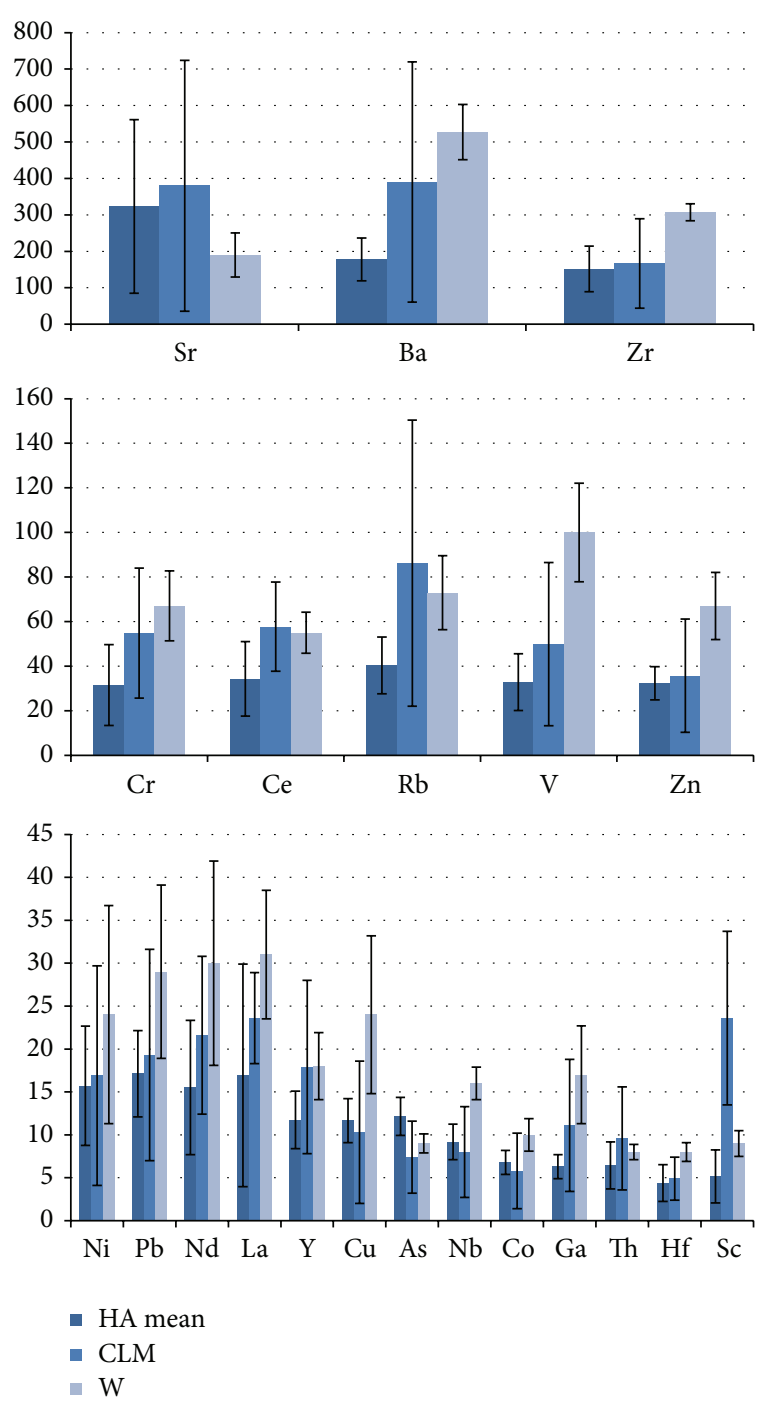

Figure 3: Representation of trace element contents $(\mathrm{mg} / \mathrm{kg})$ in surface horizons (HA) of the studied soils $(n=5)$ related to CastillaLa Mancha (CLM, [22]) and World (W, [17]) contents. Error bars show Standard Deviation.

also present at low levels. This fact can be attributed to the weak development of fungal diseases in the zone due to the climate. Higher levels of these elements have been detected in Oporto [18] (20 mg/kg for Cu and $70 \mathrm{mg} / \mathrm{kg}$ for $\mathrm{Zn})$ and in Champagne, with contents near $200 \mathrm{mg} / \mathrm{kg}$ [3]. In any case, these elements and others considered as potential pollutants $(\mathrm{Cu}, \mathrm{Zn}, \mathrm{Cd}, \mathrm{Ni}$, and $\mathrm{Mn})$ [16] are blocked in limy soils because of the high $\mathrm{pH}$ value [5] and they are not available to the plants.

The other elements studied are present at lower levels than the world averages (Figure 3), with the exception of As, which is slightly above the world average (Table 4), probably due to treatments against diseases [19].

The enrichment factor $(A / C)$ for each trace element, calculated as the value in $A$ horizon divided by the value in $C$ horizon, is given in Table 4. It can be observed that Ca depletion in the surface horizon leads to an enrichment 


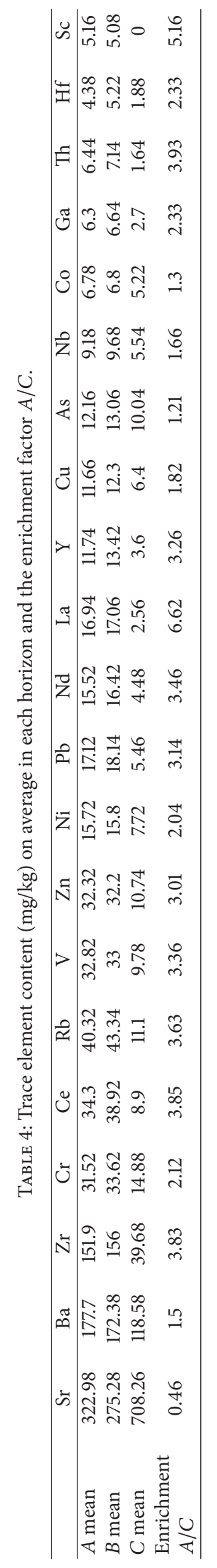


of almost all major and trace elements in the $A_{\mathrm{p}}$ and $B_{w}$ horizons. It can be stated that superficial enrichment of some trace elements is due to leaching of the original $\mathrm{Ca}$ and the moderate biological and anthropic activity.

The results state the pedologic and geochemical descriptions of a very extensive area $\left(30,000 \mathrm{~km}^{2}\right)$ of soils that spread, with local variations, over the south subplateau of the Iberian Peninsula. Sedimentary basins of Miocene origin can also be found in other zones (in Spain and the rest of the world) and a lot of information reported here could also be applied (with caution) to these soils.

\section{Conclusions}

The most prominent conclusions are as follows:

(i) weakly developed soils with a superficial horizon of variable depth, depending on the use and on the hardness of the underlying petrocalcic horizon;

(ii) intense calcic character coming from the original Miocene limestones that, in conjunction with the low rainfall, gives basic $\mathrm{pH}$, saturated exchange complex, and low mobility of most chemical elements;

(iii) superficial enrichment of trace elements due to leaching of the original $\mathrm{Ca}$ and moderate biological and anthropic activity;

(iv) the most anomalous trace element being Sr, which is present with average levels of $435 \mathrm{mg} / \mathrm{kg}$ in total and $708 \mathrm{mg} / \mathrm{kg}$ in the original rock, these values at least duplicating the average world levels;

(v) low contents of almost all other trace elements, as in the original rock; in some cases (P2) these elements coming from nearby zones with a different geological origin;

(vi) high levels of dangerous elements (Cd or $\mathrm{Hg}$ ) or pollution by metals ( $\mathrm{Pb}, \mathrm{Cu}, \mathrm{Zn}$, or $\mathrm{Ni}$ ) have not being not detected with the analytical procedures used.

\section{Conflict of Interests}

The authors declare that there is no conflict of interests regarding the publication of this paper.

\section{Acknowledgment}

This work was partially carried out under the auspices of the project "Soil Atlas of Castilla-La Mancha," financed by the Department of Agriculture of the Regional Government (Regional Government of Castilla-La Mancha).

\section{References}

[1] FAO, World Soil Resources Reports 94, Lecture Notes on the Major Soils of the World, FAO, Rome, Italy, 2001.

[2] F. Pillet, Geografía de Castilla-La Mancha, Almud, Ciudad Real, Spain, 2007.
[3] E. I. B. Chopin, B. Marin, R. Mkoungafoko et al., "Factors affecting distribution and mobility of trace elements $(\mathrm{Cu}$, $\mathrm{Pb}, \mathrm{Zn}$ ) in a perennial grapevine (Vitis vinifera L.) in the Champagne region of France," Environmental Pollution, vol. 156, no. 3, pp. 1092-1098, 2008.

[4] A. R. Hosseinpur and F. Dandanmozd, "Sorption characteristics of copper in some calcareous soils of western Iran," American Journal of Science, vol. 6, no. 11, pp. 103-108, 2010.

[5] M. Jalali and S. Moharrami, "Competitive adsorption of trace elements in calcareous soils of western Iran," Geoderma, vol. 140, no. 1-2, pp. 156-163, 2007.

[6] J. M. Alvarez, M. I. Rico, and A. Obrador, "Lixiviation and extraction of zinc in a calcareous soil treated with zinc-chelated fertilizers," Journal of Agricultural and Food Chemistry, vol. 44, no. 10, pp. 3383-3387, 1996.

[7] A. R. Đorđević, "Mobile nickel content in calcareous black soils of Rajac," Journal of Agricultural Sciences, vol. 47, no. 1, pp. 2935, 2002.

[8] J. L. De La Horra, F. Serrano, and J. J. Carlevalis, Estudio de suelos del Campo de Calatrava (Ciudad Real) y sus condiciones de fertilidad, C.S.I.C, 2008.

[9] L. Hidalgo, Caracterización Macrofísica del Ecosistema MedioPlanta en los Viñedos Españoles, I.N.I.A. Comunicaciones 29, Instituto Nacional de Investigaciones Agrarias, Madrid, Spain, 1980.

[10] J. A. Vera, Geología de España, SGE-IGME, Madrid, Spain, 2004.

[11] J. J. Carlevalis, J. L. De La Horra, F. Serrano, and J. Rodriguez, La Fertilidad de los Principales Suelos Agrícolas de la Zona Oriental de la Provincia de Ciudad Real 1, C.S.I.C., La Mancha y Campo de Montiel, Spain, J.J.C.C., Castilla-La Mancha, Spain, 1992.

[12] J. A. A. Ortiz-Villajos, C. P. de Los Reyes, F. J. G. Navarro, C. J. S. Jiménez, and R. J. Ballesta, "Description of red soils in a semiarid climate and evaluation for vineyard (Vitis vinifera L.) use," Fresenius Environmental Bulletin, vol. 19, no. 6, pp. 1199-1207, 2010.

[13] E. A. De Nadai Fernandes and F. A. Martins Bacchi, "Lanthanides in the study of lithologic discontinuity in soils from the Piracicaba river basin," Journal of Alloys and Compounds, vol. 275-277, pp. 924-928, 1998.

[14] J. J. Marques, D. G. Schulze, N. Curi, and S. A. Mertzman, “Trace element geochemistry in Brazilian Cerrado soils," Geoderma, vol. 121, no. 1-2, pp. 31-43, 2004.

[15] R. E. White, Understanding Vineyard Soils, Oxford University Press, Oxford, UK, 2009.

[16] P. Madejón, J. M. Murillo, T. Marañón, F. Cabrera, and M. A. Soriano, "Trace element and nutrient accumulation in sunflower plants two years after the Aznalcóllar mine spill," Science of the Total Environment, vol. 307, no. 1-3, pp. 239-257, 2003.

[17] A. Kabata-Pendias, Trace Elements in Soils and Plants, CRC Press, Boca Raton, Fla, USA, 3rd edition, 2001.

[18] C. M. R. Almeida and M. T. S. D. Vasconcelos, "Multielement composition of wines and their precursors including provenance soil and their potentialities as fingerprints of wine origin," Journal of Agricultural and Food Chemistry, vol. 51, no. 16, pp. 4788-4798, 2003.

[19] P. Kment, M. Mihaljevič, V. Ettler, O. Šebek, L. Strnad, and L. Rohlová, "Differentiation of Czech wines using multielement composition-a comparison with vineyard soil," Food Chemistry, vol. 91, no. 1, pp. 157-165, 2005. 
[20] G. Nicolini, R. Larcher, P. Pangrazzi, and L. Bontempo, "Changes in the contents of micro- and trace-elements in wine due to winemaking treatments," Vitis, vol. 43, no. 1, pp. 41-45, 2004.

[21] G. Gremaud, S. Quaile, U. Piantini, E. Pfammatter, and C. Corvi, "Characterization of Swiss vineyards using isotopic data in combination with trace elements and classical parameters," European Food Research and Technology, vol. 219, no. 1, pp. 97104, 2004.

[22] P. Conde, J. Martín, J. R. De la Horra, and R. JiménezBallesta, "Trace elements contents in different soils of a semiarid mediterranean environment: Castilla-La Mancha, Spain," Fresenius Environmental Bulletin, vol. 18, no. 5, pp. 858-867, 2009.

[23] R. J. Ballesta, P. C. Bueno, J. M. Rubí, and R. G. Giménez, "Pedo-geochemical baseline content levels and soil quality reference values of trace elements in soils from the Mediterranean (Castilla la Mancha, Spain)," Central European Journal of Geosciences, vol. 2, no. 4, pp. 441-454, 2010.

[24] Ministerio de Medio Ambiente Medio Medio Rural y Marino, Anuario de Estadística Agroalimentaria 2006, Ministerio de Medio Ambiente Medio Medio Rural y Marino, Madrid, Spain, 2007.

[25] J. Fanet, Les Terroirs du Vin, Hachette, 2001.

[26] FAO-ISRIC-ISSS, World Reference Base for Soil Resources 2006: A Framework for International Classification, Correlation and Communication, World Soil Resources Reports 103, FAO, 2006.

[27] Soil Survey Staff, Keys to Soil Taxonomy by Soil Survey Staff. Natural Resources Conservation Service, United States Deparment of Agriculture, Washington, DC, USA, 2006.

[28] SCS-USDA, Soil Survey Investigations Report 1. Soil Survey Laboratory Methods and Procedures for Collecting Soil Samples, U.S. Government Printing Office, Washington, DC, USA, 1972.

[29] G. W. Gee and J. W. Bauder, "Particle-size analysis," in Methods of Soil Analysis. Part 1. Physical and Mineralogical Methods, A. Klute, Ed., Agronomy Monograph no. 9, pp. 383-411, ASASSSA, Madison, Wis, USA, 2nd edition, 1986.

[30] S. R. Olsen, C. V. Cole, F. S. Watanabe, and L. A. Dean, Estimation of Available Phosphorus in Soils by Extraction with Sodium Bicarbonate, US Department of Agriculture CIRC, 1954.

[31] D. W. Nelson and L. E. Sommers, "Total carbon, organic carbon and organic matter," in Methods of Soil Analysis, A. L. Page, D. H. Miller, and D. R. Keeney, Eds., pp. 539-579, ASA, SSSA, Madison, Wis, USA, 1982.

[32] G. W. Thomas, "Exchangeable cations," in Methods of Soil Analysis. Part 2. Chemical and Microbiological Properties, A. L. Page, R. H. Miller, and D. R. Keeney, Eds., pp. 159-165, American Society of Agronomy, Soil Science Society of America, Madison, Wis, USA, 1982.

[33] J. M. Bremner and C. S. Mulvaney, "Nitrogen total," in Methods of Soil Analysis Part 2: Chemical and Microbiological Properties, A. L. Page, Ed., pp. 621-622, American Society of Agronomy and Soil Science Society of America, Madison, Wis, USA, 2nd edition, 1982.

[34] F. J. G. Navarro, J. A. A. Ortiz-Villajos, C. J. S. Jiménez, and R. J. Ballesta, "Red soil geochemistry in a semiarid Mediterranean environment and its suitability for vineyards," Environmental Geochemistry and Health, vol. 33, no. 3, pp. 279-289, 2011.

[35] A. Wild, Condiciones del Suelo y el Desarrollo de las Plantas según Russel, Mundiprensa, Madrid, Spain, 1992.

[36] D. L. Sparks, Environmental Soil Chemistry, Elsevier, 2nd edition, 2003.
[37] H. Rollinson, Using Geochemical Data: Evaluation, Presentation, Interpretation, Pearson Education, New York, NY, USA, 1993. 

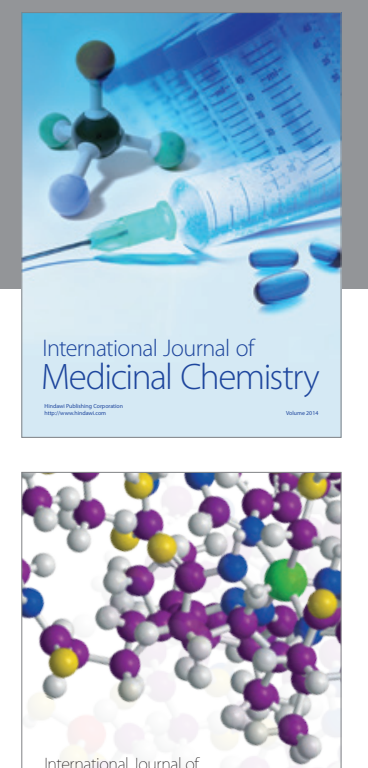

\section{Carbohydrate} Chemistry

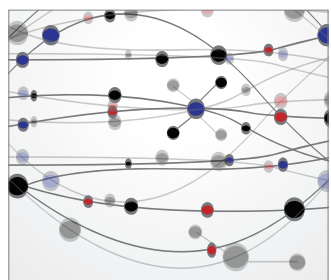

The Scientific World Journal
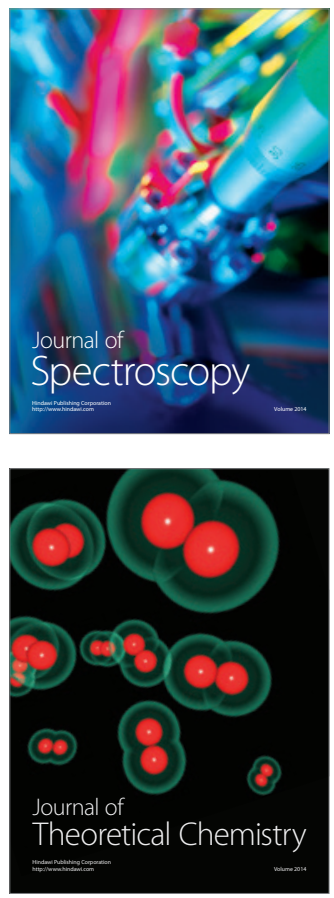
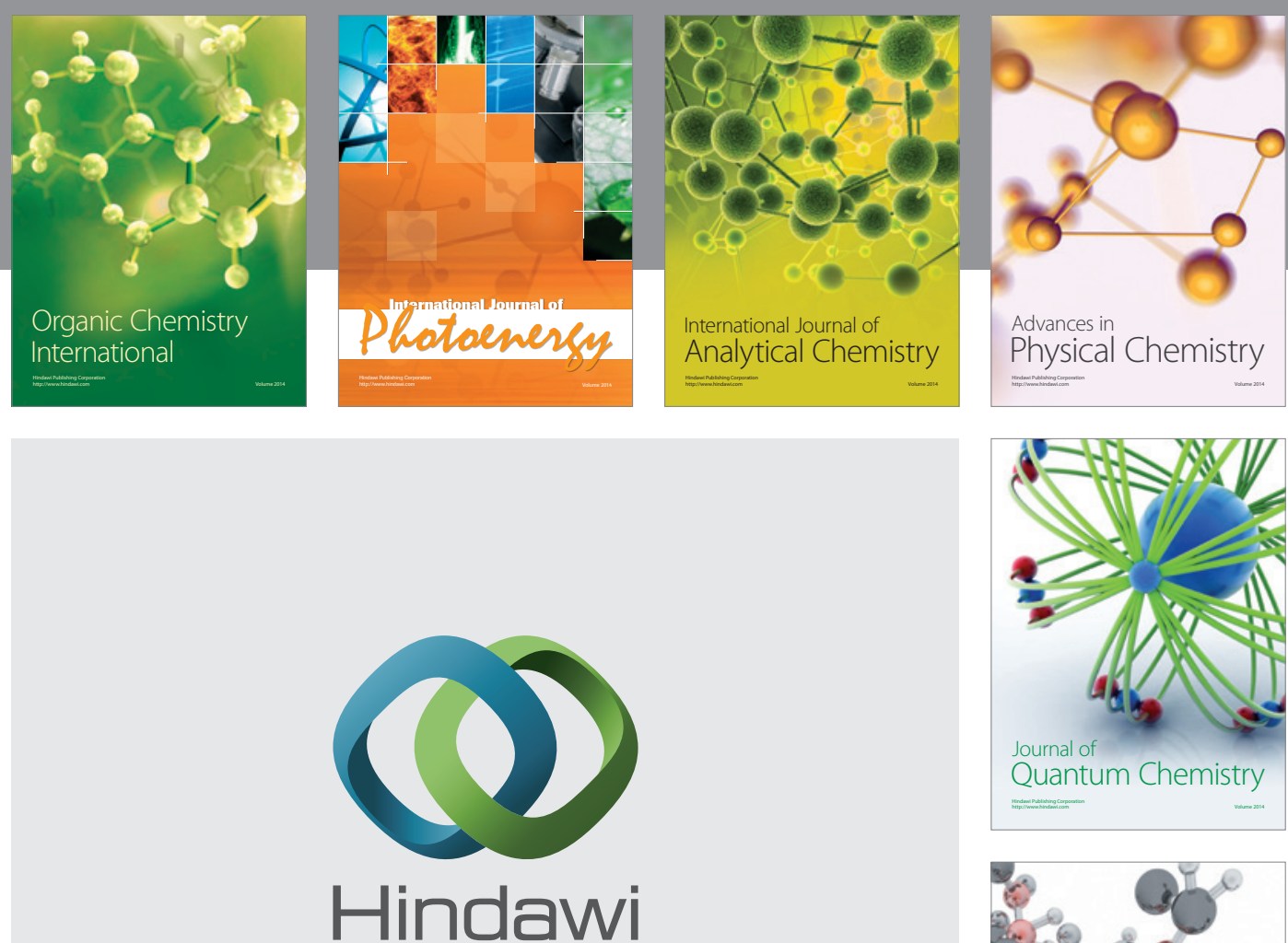

Submit your manuscripts at

http://www.hindawi.com

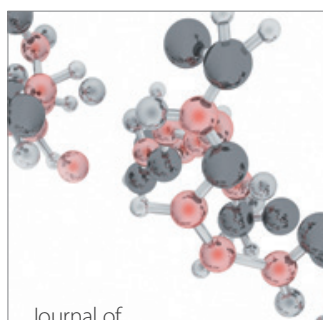

Analytical Methods

in Chemistry

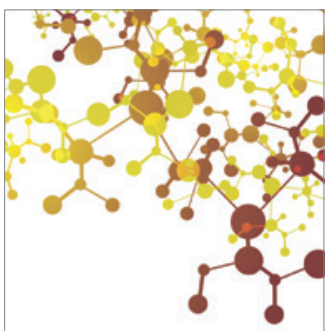

Journal of

Applied Chemistry

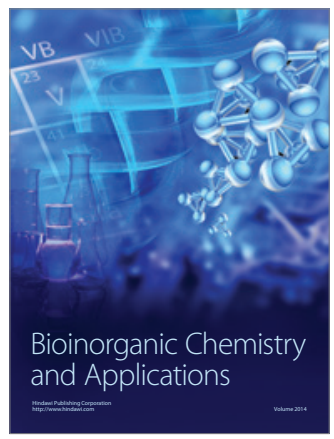

Inorganic Chemistry
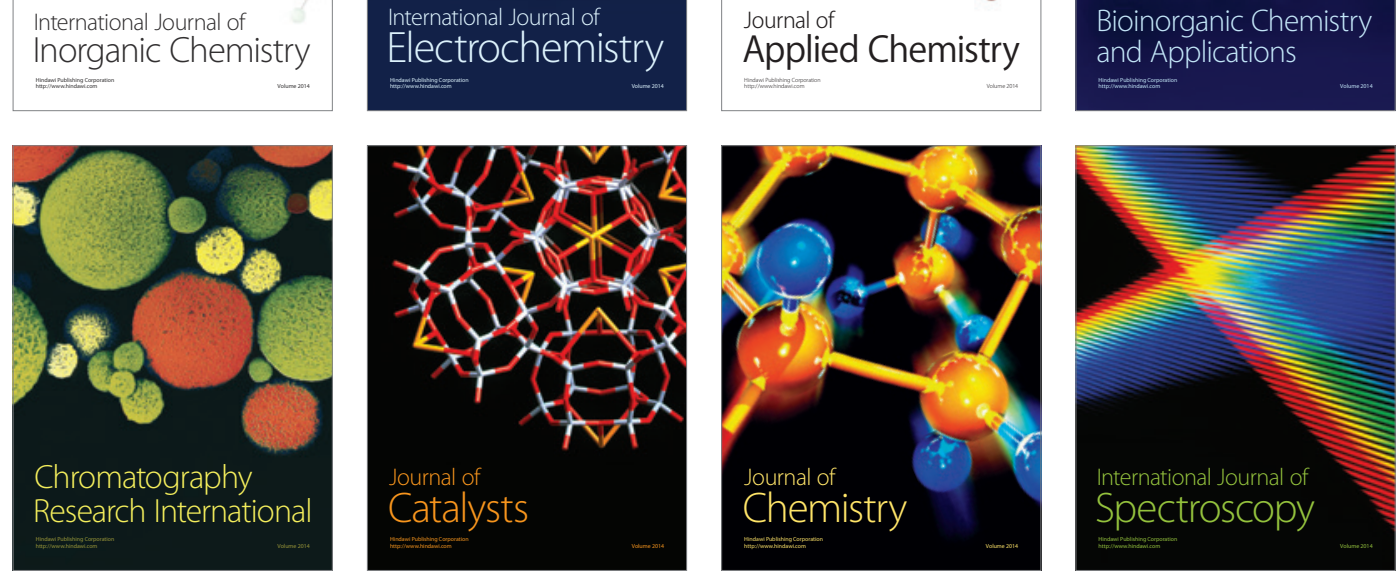